\title{
A survey on auditing, quality assurance systems and legal frameworks in five selected slaughterhouses in Bulawayo, south-western Zimbabwe
}

\author{
Authors: \\ Kaurai E. Masanganise ${ }^{1}$ \\ Gift Matope 2 \\ Davies M. Pfukenyi ${ }^{3}$ \\ Affiliations: \\ ${ }^{1}$ Department of Veterinary \\ Technical Services, Veterinary \\ Public Health Branch, \\ Bulawayo, Zimbabwe \\ ${ }^{2}$ Department of Paraclinical \\ Veterinary Studies, Faculty \\ of Veterinary Science, \\ University of Zimbabwe, \\ Zimbabwe \\ ${ }^{3}$ Department of Clinical \\ Veterinary Studies, Faculty \\ of Veterinary Science, \\ University of Zimbabwe, \\ Zimbabwe \\ Correspondence to: \\ Davies Pfukenyi \\ Email: \\ dmpfukenyi@vet.uz.ac.zw \\ Postal address: \\ PO Box MP167, Mt Pleasant, \\ Harare, Zimbabwe \\ Dates: \\ Received: 09 Feb. 2013 \\ Accepted: 08 May 2013 \\ Published: 28 June 2013 \\ How to cite this article: \\ Masanganise, K.E., Matope, \\ G. \& Pfukenyi, D.M., 2013, 'A \\ survey on auditing, quality \\ assurance systems and legal \\ frameworks in five selected \\ slaughterhouses in Bulawayo, \\ south-western Zimbabwe', \\ Onderstepoort Journal of \\ Veterinary Research 80(1), \\ Art. \#575, 8 pages. http:// \\ dx.doi.org/10.4102/ojvr. \\ v80i1.575

\section{Copyright:} \\ (C) 2013. The Authors. \\ Licensee: AOSIS \\ OpenJournals. This work \\ is licensed under the \\ Creative Commons \\ Attribution License. \\ Read online:

The purpose of this study was to explore the audits, quality assurance (QA) programmes and legal frameworks used in selected abattoirs in Zimbabwe and slaughterhouse workers' perceptions on their effectiveness. Data on slaughterhouse workers was gathered through a self-completed questionnaire and additional information was obtained from slaughterhouse and government records. External auditing was conducted mainly by the Department of Veterinary Public Health with little contribution from third parties. Internal auditing was restricted to export abattoirs. The checklist used on auditing lacked objective assessment criteria and respondents cited several faults in the current audit system. Most respondents (>50.0\%) knew the purposes and benefits of audit and QA inspections. All export abattoirs had QA programmes such as hazard analysis critical control point and ISO 9001 (a standard used to certify businesses' quality management systems) but their implementation varied from minimal to nil. The main regulatory defect observed was lack of requirements for a QA programme. Audit and quality assurance communications to the selected abattoirs revealed a variety of non-compliances with most respondents revealing that corrective actions to audit (84.3\%) and quality assurance (92.3\%) shortfalls were not done. A high percentage of respondents indicated that training on quality $(76.8 \%)$ and regulations $(69.8 \%)$ was critical. Thus, it is imperative that these abattoirs develop a food safety management system comprising of QA programmes, a microbial assessment scheme, regulatory compliance, standard operating procedures, internal and external auditing and training of workers.

\section{Introduction}

The establishment and functioning of slaughterhouses is governed by audits, quality assurance (QA) systems and legislation. Thus, a food safety management system (FSMS) implemented in a slaughterhouse should be based on good hygienic practices (GHP) and hazard analysis critical control point (HACCP) principles and, should address both food safety control and assurance activities in order to guarantee food safety (Luning \& Marcelis 2007; Jacxsens, Devlieghere \& Uyttendaele 2009a). Nowadays, several QA standards are available, like the ISO 22000 (ISO 2005), the international food standard (IFS 2007), and the global standard for food safety (BRC 2008), which were specifically developed for food processing industries. However, one of the emerging challenges is the translation and implementation of the QA and legislative requirements into a slaughterhouse FSMS and to assess the performance of a present FSMS (Jacxsens et al. 2009b). As a consequence, various audit tools have been developed to determine the performance of QA standards (Wallace, Powell \& Holyoak 2005; CIES 2007; Cormier et al. 2007; Domenech et al. 2008), which check on compliance to the set requirements during internal or external auditing (Van der Spiegel et al. 2005).

Auditing is a valuable, systematic and independent tool for verification which functions by examining and evaluating the adequacy and effectiveness of other controls (Howlett, Bolton \& $\mathrm{O}^{\prime}$ Sullivan 2005). It is a scientific approach to a process, designed to prevent occurrence of problems by verification of evidence that exists and is applied at critical production stages. Thus, the process of auditing verifies the parameters of product quality in relation to product compliance on specifications, legislation, QA standards and customer specifications. According to Hepner, Wilcock and Aung (2004), through auditing, companies can verify their practices and improve the consistency of their products and services. A certification audit issued by several accredited third parties and/or the national food agency should give confidence on the compliance to the requirements of certain QA standards (Van Gerven et al. 2007; Albersmeier et al. 2009). Hence, auditing activities and continual improvement initiatives designed to meet public health authority requirements and customer expectations can be used as a predictor of a company's future success in the market place (Hepner et al. 2004). 
However, questions arise on the effectiveness of audits in driving the continual improvement of slaughterhouse FSMS and the implementation and/or contribution of QA programs such as HACCP, GHP, ISO and total quality management (TQM) towards improving food safety in developing countries such as Zimbabwe. Although the contribution to food safety of QA systems has been investigated predominantly in developed countries (Jacxsens et al. 2011; Luning et al. 2011; Sampers et al. 2012), no work has been done on the role of auditing, QA systems and legal frameworks in the Zimbabwean meat industry. Given the economic depression that has affected the implementation and monitoring of QA systems, investigation of this topic was warranted. This paper explored the auditing activities, QA systems and legal frameworks in use in selected abattoirs in the country. Specifically, the objectives of this study were to determine: who carries out the audit and what is being audited in the slaughterhouses, how audit results are being used, the types of QA systems and legal frameworks in operation and the knowledge and awareness of slaughterhouse personnel on the role of audits, QA systems and legal frameworks on food safety.

\section{Materials and methods Study location}

Zimbabwe is located in Southern Africa, between $25^{\circ} \mathrm{E}$ and $33^{\circ} \mathrm{E}$ and $16^{\circ} \mathrm{S}$ and $22^{\circ} \mathrm{S}$, with a subtropical climate that is characterised by seasonal rainfall (November to March) and a dry period (April to October). The country is divided into eight administrative provinces that are further split into several districts. The slaughterhouses were selected in Bulawayo, which is located in south-western Zimbabwe. Their selection was based on their slaughter capacities of different food animals. The five selected slaughterhouses included three for cattle (abattoirs A, B and C), one for ostriches (abattoir D) and one for chickens (abattoir E). Two cattle abattoirs (A and B) were exporting plants, whilst the other was a non-exporting abattoir. The ostrich and chicken slaughterhouses were both export plants.

\section{Data collection and analysis}

A cross-sectional questionnaire-based study on slaughterhouse personnel was employed to investigate several aspects of the audits, QA systems and legal frameworks of each of the selected abattoirs. The study was conducted between March and November 2010 and pre-tested structured questionnaires with multiple-choice and open-ended questions were used. Self-completion questionnaires were administered to at least $10 \%$ of randomly selected slaughterhouse personnel of each selected abattoir. An initial visit was made to one slaughterhouse not selected for the study, where a few abattoir personnel were interviewed and the ease of completion of the questionnaire and lack of clarity of questions were noted and the questionnaire subsequently revised.

The questionnaire was designed to obtain information on the purpose, frequency, benefits, flaws or faults and effectiveness of the current audit and quality management systems and legal framework pertaining at the abattoirs. Slaughterhouse personnel were asked about organisations carrying out audits and QA inspections and whether slaughterhouse personnel prepared for audits and QA inspections. They were also asked which areas were audited or inspected, whether they received feedback of previous audits, actions taken after audits or quality inspections, abattoir rating or grading after audits and quality incentives. Additional information on quality included awareness, knowledge and type of quality systems used. The questionnaire on legal frameworks also included awareness and knowledge of the legal framework, organisations responsible for informing, educating and implementing the legal framework and penalties for contravening the legislation.

In order to support and verify the information obtained from the questionnaires, additional information was collected from slaughterhouse and government records. Abattoir and government records related to audits (import health certificates, policy documents, minutes, circulars, audit results communications) and those related to QA systems (quality manuals, policy documents, minutes, circulars, quality inspection results communications, QA reports, mission statements, organisational objectives, maintenance schedules, standard operation procedures and other sanitary documents) were consulted for the six-year period January 2002 to December 2007. Records related to audits were perused with regard to dates of audits, organisations carrying out the audits, areas audited, results of audits, faults identified during audits and corrective measures taken. Those related to quality systems were perused with regard to dates of inspections, organisations carrying out inspections, areas inspected, results of inspections, faults identified during inspections and corrective measures taken. In addition, observations for evidence of QA maintenance were also carried out. Furthermore, legislation and government policies pertaining to audits and quality management of abattoirs in Zimbabwe were also consulted to supplement information gained through the legal framework section of the questionnaire. Observation and analysis of the government structural set-up was also done in relation to application of the legislation pertaining to slaughterhouses.

The data analysis focused on generation of descriptive statistics (frequencies or proportions) related to issues concerned with audit and quality assurance systems and legal frameworks.

\section{Results}

Abattoir records and observations on audits, quality and legal framework inspection of abattoir audits and QA systems records for the period 2002-2007 showed that all the five abattoirs were audited mainly by the Department of Veterinary Public Health (DVPH). Three checklists were designed and used during abattoir audits, with the first focusing on areas of structural audits, the second on activitybased audits and the third on structural and operational 
conformity audits (Table 1). Performance ratings were as follows: $\mathrm{A}=$ exceed standards, $\mathrm{B}=$ meets minimum standards, $\mathrm{C}=$ not in accordance with standards and $\mathrm{D}=$ poor compliance. All the exporting abattoirs had QA programmes; three had HACCP and one was accredited by the standards association of Zimbabwe (SAZ) ISO 9001 but implementation of the system varied from minimal to nil (Table 2). The exporting abattoirs had either a quality policy statement or mission and vision statements.

There was a general non-response to audit and quality assurance recommendations in all the five selected abattoirs

\begin{tabular}{|c|c|}
\hline Type of checklist & Areas audited \\
\hline \multirow{5}{*}{$\begin{array}{l}\text { Structural } \\
\text { audits }\end{array}$} & Lairages \\
\hline & $\begin{array}{l}\text { Raceway, stunning, bleeding, scalding, de-hairing, hoof- } \\
\text { removal, singeing, evisceration and inspection areas }\end{array}$ \\
\hline & Railing height \\
\hline & Foot baths \\
\hline & Hand wash and medical or first aid facilities \\
\hline \multirow{9}{*}{$\begin{array}{l}\text { Activity-based } \\
\text { audits }\end{array}$} & Stunning method \\
\hline & Bleeding efficiency \\
\hline & Plucking or skinning and evisceration efficiency \\
\hline & Movement of carcass along rails \\
\hline & Maintenance of water temperatures \\
\hline & Personal hygiene \\
\hline & Lighting and ventilation \\
\hline & Standard operation procedures \\
\hline & Operation procedure documents (e.g. product traceability) \\
\hline \multirow{14}{*}{$\begin{array}{l}\text { Structural and } \\
\text { operational } \\
\text { conformity } \\
\text { audits }\end{array}$} & Perimeter fence \\
\hline & Roads \\
\hline & Receiving, dispatching, processing and grounds areas \\
\hline & Foot baths \\
\hline & Slaughterhouse superstructure \\
\hline & Refrigeration, water supply, hand wash and ablution facilities \\
\hline & Protective clothing \\
\hline & Medical records \\
\hline & Pest control \\
\hline & Quality assurance system \\
\hline & Waste management and drainage \\
\hline & Transportation vehicles wash system \\
\hline & Canteen \\
\hline & Security, wear and tear of structures \\
\hline
\end{tabular}

TABLE 2: Quality management systems used in the five selected abattoirs.

\begin{tabular}{|c|c|c|}
\hline Abattoir & Type & Quality assurance program or standard \\
\hline \multirow[t]{2}{*}{ A (Cattle) } & Exporting & $\begin{array}{l}\text { SAZ ISO } 9001 \text { programme with evidence } \\
\text { of documentation but minimal } \\
\text { implementation of the quality programme }\end{array}$ \\
\hline & & $\begin{array}{l}\text { Vision and mission statements pertaining } \\
\text { to quality of products }\end{array}$ \\
\hline B (Cattle) & Exporting & $\begin{array}{l}\text { HACCP with evidence of documentation } \\
\text { but no implementation of the quality } \\
\text { programme }\end{array}$ \\
\hline C (Cattle) & Non-Exporting & $\begin{array}{l}\text { No quality assurance program and no } \\
\text { quality policy statement or vision and } \\
\text { mission statements in place }\end{array}$ \\
\hline \multirow[t]{2}{*}{ D (Ostriches) } & Exporting & $\begin{array}{l}\text { HACCP programme with evidence of } \\
\text { documentation last reviewed in } 2003 \text {. }\end{array}$ \\
\hline & & $\begin{array}{l}\text { Quality Policy Statement addressing } \\
\text { slaughtering and processing of meat } \\
\text { products in accordance with international } \\
\text { standards and regulations }\end{array}$ \\
\hline \multirow[t]{2}{*}{ E (Chickens) } & Exporting & $\begin{array}{l}\text { HACCP with evidence of documentation } \\
\text { and implementation of the quality } \\
\text { programme }\end{array}$ \\
\hline & & $\begin{array}{l}\text { Quality Policy Statement addressing } \\
\text { production of safe meat products }\end{array}$ \\
\hline
\end{tabular}

for the period 2002-2007 (Table 3). The main shortfalls identified were lack of repair or replacement of non-functional structures or equipment, absence or shortage of sterilising and hot water supply, shortage of protective clothing and detergents, improper methods of waste disposal, lack of hygiene and sanitary conditions, a backlog on residue tests, lack of arrangement for full medical examinations of workers, non-labelling of condemnation rooms and high microbial counts on carcasses and utensils. Three exporting abattoirs had their own internal quality assurance communication system whilst two had none. Analysis of government records showed that there were no policies and circulars relating

TABLE 3: Shortfalls identified on the analysis of audit and quality communications for the five selected abattoirs for the period January 2002 to December 2007.

\begin{tabular}{|c|c|c|}
\hline Abattoir & Type & Shortfalls \\
\hline \multirow[t]{6}{*}{ A (Cattle) } & Exporting & $\begin{array}{l}\text { Shortage of hot water supply, protective } \\
\text { clothing and detergents }\end{array}$ \\
\hline & & $\begin{array}{l}\text { Poor waste disposal and sanitary } \\
\text { conditions }\end{array}$ \\
\hline & & $\begin{array}{l}\text { Deterioration of artificial lighting, painting } \\
\text { and ceiling of rooms }\end{array}$ \\
\hline & & $\begin{array}{l}\text { Poor cleaning (working tables, machinery, } \\
\text { floors and canteen) }\end{array}$ \\
\hline & & $\begin{array}{l}\text { Low HACCP standards, lack of quality } \\
\text { awareness and GMP Manual }\end{array}$ \\
\hline & & $\begin{array}{l}\text { High microbial counts on carcasses and } \\
\text { utensils }\end{array}$ \\
\hline \multirow[t]{8}{*}{ B (Cattle) } & Exporting & $\begin{array}{l}\text { Non-replacement of broken windows and } \\
\text { worn out protective clothing }\end{array}$ \\
\hline & & $\begin{array}{l}\text { No repair and repainting of abattoir } \\
\text { facilities (toilets, walls, floors, ceilings, cold } \\
\text { rooms and passages) }\end{array}$ \\
\hline & & No control of water dripping from ceiling \\
\hline & & No drinking water facilities for animals \\
\hline & & $\begin{array}{l}\text { No improvement on cleaning of abattoir } \\
\text { facilities (floors, drains, cold rooms, etc.) }\end{array}$ \\
\hline & & Non-labelling of measles detention rooms \\
\hline & & $\begin{array}{l}\text { No immediate loading of products } \\
\text { in dispatch to minimize temperature } \\
\text { fluctuations }\end{array}$ \\
\hline & & High microbial counts on carcasses \\
\hline \multirow[t]{5}{*}{ C (Cattle) } & Non-Exporting & $\begin{array}{l}\text { Non-replacement, repair and repainting } \\
\text { of abattoir facilities (fly screens, windows, } \\
\text { lockers, steam leaks in by-products and } \\
\text { changing rooms) }\end{array}$ \\
\hline & & $\begin{array}{l}\text { Non-provision of fly traps, lagging of hot } \\
\text { water pipes and labeling of condemnation } \\
\text { rooms }\end{array}$ \\
\hline & & $\begin{array}{l}\text { No recommended carcass spacing, hose } \\
\text { holder in passage area and pressure } \\
\text { nozzles on hoses in dressing room }\end{array}$ \\
\hline & & $\begin{array}{l}\text { No arrangement for full medical } \\
\text { examinations of workers and poor cleaning } \\
\text { (canteen) }\end{array}$ \\
\hline & & High microbial counts on carcasses \\
\hline \multirow[t]{5}{*}{$\mathrm{D}$ (Ostriches) } & Exporting & Residue backlog \\
\hline & & Absence of meat inspectors at times \\
\hline & & No checking on loading of export trucks \\
\hline & & $\begin{array}{l}\text { Build-up of carcasses before inspection and } \\
\text { movement to chillers (up to } 25 \text { ) }\end{array}$ \\
\hline & & Dirty workers in clean canteen \\
\hline \multirow[t]{6}{*}{ E (Chickens) } & Exporting & $\begin{array}{l}\text { Absence of sterilising water and scalding } \\
\text { tank thermo-regulator }\end{array}$ \\
\hline & & Dysfunctional hand wash facilities \\
\hline & & Flaking ceiling \\
\hline & & $\begin{array}{l}\text { Long grass on factory grounds (rainy } \\
\text { season) }\end{array}$ \\
\hline & & Management not cooperative \\
\hline & & $\begin{array}{l}\text { High microbial counts on carcasses and } \\
\text { utensils }\end{array}$ \\
\hline
\end{tabular}


to quality assurance issues. However, quality assurance issues such as health and hygiene status of workers and health markings on carcasses were reflected on statutory instruments.

Inspection of abattoir legal framework for the same period showed that the following pieces of legislation promulgated for slaughterhouse operations or activities in Zimbabwe were operational: slaughtering and meat inspection regulation (Government of Zimbabwe 1945), Public Health Act (Government of Zimbabwe 1996) and statutory instruments 111 (Government of Zimbabwe 1984) and 50 (Government of Zimbabwe 1995). These regulations have sections dealing with audit and quality assurance and, give provision for meat inspectors to enter abattoir premises to ascertain contraventions of regulations, licensing and registration of the abattoirs, deregistration of non-complying abattoirs, movement permits for live animals to slaughter and powers of a meat inspector. The main regulatory defects noted were lack of standard operating procedures in abattoir registration, lack of requirements for a quality assurance system and employees' knowledge on abattoir operations and lack of mechanisms to enforce maintenance of standards by abattoirs. In addition, there was no communication on audit or quality assurance which referred to the legal framework.

Major observations included the following: lack of adequately trained abattoir and government staff on food safety and legislative issues, control and management of abattoir based on management or staff's perceptions, showcases rather than real scenarios on audits and quality inspections and, pressure for high production at all costs with no regard to quality assurance and legal requirements.

\section{Questionnaire responses}

A total of 300 questionnaires were distributed to the five selected abattoirs; 100 each for audit, quality and legal framework with 20 for each abattoir on audit, quality assurance and legislation. The overall response rate on audit, quality assurance and legislation was 51.0\%, 78.0\% and $86.0 \%$, respectively. Individual abattoir response rates ranged from $35.0 \%$ to $60.0 \%$ for audit, $50 \%$ to $100.0 \%$ for quality and $70.0 \%$ to $90.0 \%$ for legislation framework. Most respondents were male; $94.1 \%(48 / 51)$ for audit, $89.7 \%$ $(70 / 78)$ for quality and $97.7 \%(84 / 86)$ for legislation. Overall, $69.3 \%(149 / 215)$ of the respondents had more than five years' work experience, $71.2 \%(153 / 215)$ were over 30 years of age and $51.6 \%(111 / 215)$ had formal training in meat hygiene.

Respondents from all abattoirs indicated that their abattoirs were audited (100.0\%) and used a legal framework (84.0\%). All respondents from exporting abattoirs indicated that they had a quality assurance system. HACCP (81.8\%) and GHP (29.2\%) by respondents from three export abattoirs and, ISO $9001(90.0 \%)$ and ISO $22000(10.0 \%)$ by respondents from one export abattoir were named as the quality systems or standards used, respectively. The legal frameworks used by the abattoirs were indicated as the Public Health Act by respondents from all abattoirs (58.1\%), Statutory Instruments 111 of 1984 by respondents from two abattoirs (50.0\%) and 50 of 1995 by respondents from four abattoirs (44.1\%) and local authority by-laws by respondents from three abattoirs $(44.4 \%)$.

Most respondents from all abattoirs revealed that the DVPH was in charge of auditing (76.5\%), checking on quality $(92.0 \%)$ and adherence to regulations (86.0\%). However, internal auditors $(41.2 \%)$, local authority departments (37.9\%) and other organisations (41.2\%) such as SAZ and customers were also indicated as auditors by respondents from three export abattoirs. The quality department (57.1\%), management $(47.6 \%)$ and staff $(28.6 \%)$ were also indicated by respondents from two exporting abattoirs as responsible for quality assurance programmes. Similarly, the quality department $(25.9 \%)$, management $(41.2 \%)$ and staff $(22.2 \%)$ were also indicated by respondents from these two abattoirs as responsible for enforcing regulations.

Compared to checks on regulations (26.5\%), higher percentages of respondents indicated that audits $(86.3 \%)$ and quality checks $(56.4 \%)$ were done once a year. Most respondents $(98.0 \%)$ from all abattoirs agreed that their organisations prepare for audits. Higher percentages of respondents from all abattoirs indicated that immediate brief meetings were done to summarise and communicate audit (90.2\%) and quality (84.6\%) findings and that full requirements of legal frameworks $(93.0 \%)$ were communicated to their organisations. Similarly, most respondents revealed that corrective actions were not done on audit (84.3\%), quality (92.3\%) and regulatory (93.0\%) shortfalls.

Approximately $55.0 \%$ of respondents from all export abattoirs were aware of abattoir ratings given after audits, but a low percentage $(42.3 \%)$ from three export abattoirs were aware of quality incentives given to their abattoirs. Respondents from all abattoirs felt that the introduction of abattoir ratings $(68.6 \%)$ and quality assurance incentives (87.2\%) was beneficial. A higher percentage of the respondents (90.7\%) agreed that penalties exist for breaching regulations and suspension $(88.4 \%)$ was the penalty mentioned. However, over $90.0 \%$ of the respondents from all abattoirs agreed that audits, quality and regulation checks were beneficial. Improved customer satisfaction, product quality assurance, sales, deficiency identification and working conditions were named as the benefits (Table 4).

Compliance with regulations and standards, renewal of registration and enforcement of regulations were indicated as the main purposes of audit, quality and regulatory checks. However, $17.0 \%$ to $38.5 \%$ of the respondents also indicated that audit, quality and regulatory checks were meant for fault finding (Table 4). Except for ante-mortem inspection and test records, transportation and recall procedures, over $50.0 \%$ of the respondents were aware of areas to be audited, checked for quality and compliance to regulations (Table 4). Most respondents indicated that the current audit (76.5\%) and 
TABLE 4: Summary of responses to major issues on audit, quality and legal frameworks.

\begin{tabular}{|c|c|c|c|c|c|c|c|c|c|c|}
\hline \multirow[t]{2}{*}{ Variable } & \multirow[t]{2}{*}{ Responses } & \multicolumn{3}{|c|}{ Audit $(n=51)$} & \multicolumn{3}{|c|}{ Quality assurance $(n=78)$} & \multicolumn{3}{|c|}{ Legal framework $(n=86)$} \\
\hline & & No. & $\%$ & Abattoirs & No. & $\%$ & Abattoirs & No. & $\%$ & Abattoirs \\
\hline \multirow{5}{*}{$\begin{array}{l}\text { Benefits derived } \\
\text { from audits, quality and } \\
\text { regulatory checks }\end{array}$} & Improved customer satisfaction & 32 & 62.8 & 5 & 66 & 84.6 & 5 & 66 & 76.7 & 5 \\
\hline & Improved product quality & 43 & 84.4 & 5 & 72 & 92.3 & 5 & 80 & 93.0 & 5 \\
\hline & Improved sales & 21 & 42.6 & 5 & 48 & 61.5 & 5 & 58 & 67.4 & 5 \\
\hline & Improved deficiency identification & 32 & 62.8 & 5 & - & - & - & - & - & - \\
\hline & Improved work conditions & - & - & - & 50 & 48.5 & 4 & 56 & 65.1 & 5 \\
\hline \multirow{6}{*}{$\begin{array}{l}\text { Purpose of audits, quality and } \\
\text { regulatory checks }\end{array}$} & Compliance to standards & 36 & 70.6 & 5 & 52 & 63.6 & 4 & - & - & - \\
\hline & Compliance to regulations & - & - & - & 62 & 79.5 & 5 & - & - & - \\
\hline & Registration & 22 & 43.1 & 5 & - & - & - & - & - & - \\
\hline & Enforcement of standards & - & - & - & 53 & 67.4 & 5 & 50 & 58.1 & 5 \\
\hline & Enforcement of regulations & - & - & - & - & - & - & 72 & 83.7 & 5 \\
\hline & Fault finding & 12 & 17.1 & 4 & 30 & 38.5 & 5 & 23 & 17.6 & 4 \\
\hline \multirow{13}{*}{$\begin{array}{l}\text { Areas audited, quality and } \\
\text { regulatory checked }\end{array}$} & Premises & 47 & 93.2 & 5 & 72 & 92.3 & 5 & 80 & 93.0 & 5 \\
\hline & Water & 37 & 72.4 & 5 & 62 & 79.5 & 5 & 72 & 83.7 & 5 \\
\hline & Personnel & 27 & 52.6 & 5 & 58 & 74.4 & 5 & 68 & 79.0 & 5 \\
\hline & Slaughter records & 34 & 66.4 & 5 & 54 & 69.2 & 5 & 66 & 76.7 & 5 \\
\hline & Ante mortem inspection records & 23 & 44.2 & 5 & 48 & 61.5 & 5 & 62 & 72.1 & 5 \\
\hline & Post mortem records & 30 & 58.2 & 5 & 56 & 71.8 & 5 & 62 & 72.1 & 5 \\
\hline & Test records & 25 & 49.0 & 5 & 58 & 74.4 & 5 & 66 & 76.6 & 5 \\
\hline & Transportation & 20 & 38.6 & 5 & 56 & 71.8 & 5 & 54 & 62.8 & 5 \\
\hline & Meat product quality & 30 & 58.0 & 4 & 64 & 82.1 & 5 & 58 & 67.4 & 5 \\
\hline & Packaging \& labeling & 26 & 51.0 & 4 & 54 & 69.2 & 5 & 46 & 53.5 & 5 \\
\hline & Condemnation records & 33 & 64.0 & 5 & 44 & 56.4 & 5 & 66 & 76.7 & 5 \\
\hline & Cleanliness \& hygiene & - & - & - & 76 & 97.4 & 5 & 76 & 88.6 & 5 \\
\hline & Recall procedures & - & - & - & 40 & 51.3 & 5 & 42 & 48.8 & 5 \\
\hline \multirow{10}{*}{$\begin{array}{l}\text { Faults on current audit and } \\
\text { quality systems \& legal } \\
\text { framework }\end{array}$} & Fault finding & 19 & 37.3 & 5 & 20 & 25.6 & 5 & 22 & 25.6 & 5 \\
\hline & No transparency & 16 & 31.4 & 5 & - & - & - & - & - & - \\
\hline & Not measured against published standards & 15 & 29.3 & 4 & - & - & - & - & - & - \\
\hline & Not objective & 13 & 20.9 & 4 & 6 & 7.7 & 5 & - & - & - \\
\hline & Lack of expertise & 9 & 17.6 & 5 & 22 & 28.1 & 5 & 22 & 25.4 & 5 \\
\hline & Not rooted in organization & - & - & - & 32 & 41.0 & 5 & 33 & 398.5 & 5 \\
\hline & Centered on few individuals & - & - & - & 26 & 33.3 & 5 & 11 & 12.8 & 5 \\
\hline & Requires application skills & - & - & - & 60 & 76.9 & 5 & 62 & 72.5 & 5 \\
\hline & Not concerned with quality & - & - & - & & - & - & 19 & 22.5 & 5 \\
\hline & Not penalizing enough & - & - & - & & - & - & 35 & 41.0 & 5 \\
\hline
\end{tabular}

quality (71.8\%) system checks and, legal framework (90.7\%) were effective. However, except for skills requirement on quality $(76.9 \%)$ and regulations $(72.5 \%)$ application, low percentages of respondents $(<44.0 \%)$ indicated major faults in the current audit, quality and legal frame work systems (Table 4). A higher percentage of respondents from all abattoirs agreed that training on quality assurance (76.8\%) and regulations $(69.8 \%)$ is important.

\section{Discussion}

Legislation is necessary to ensure food safety (Adams \& Brülisauer 2010) with the competent authority having legal powers to set and enforce regulatory meat hygiene requirements (Benet \& Bellemain 2005; Benet et al. 2006; McKenzie \& Hathaway 2006). As observed elsewhere (Hepner et al. 2004), results of the present study showed that audits, quality and regulatory checks in Zimbabwe were predominantly carried out by DVPH, a government regulatory authority. Their involvement in food safety inspections is essential in the promotion of safe and quality of meat products. In the European Union (EU), the responsibility for compliance with set standards rests with the food operator and this is enforced by the competent authority in each member state (Adams \& Brülisauer 2010). Hence, despite inspection by the competent authority, operators of slaughterhouses in Zimbabwe should take the leading role in compliance with standards.

As reported by Hepner et al. (2004), internal auditing was found to be limited to exporting abattoirs. Although export is naturally very important to a country there should also be minimum standards for preparation of meat irrespective of its destination. In some European countries, the enactment of the new hygiene regulations is reported to move towards technically classifying local authority slaughterhouses and exporting abattoirs as one, with all carcasses and meat products identifiable with the same EU health brand (Howlett et al. 2005). It is therefore imperative for Zimbabwe to move towards similar classification of domestic and exporting 
abattoirs. The observed annual external audits carried out by the DVPH appear to be insufficient to meet the demands for continual improvement (Hepner et al. 2004). Internal and external audits are both integral parts of an effective quality control programme (Hepner et al. 2004). Internal audits are an important component of the quality control programme and should ideally be carried out at least bi-annually. Thus, assuming an active role in internal auditing, rather than a reactive response to external audits and compliance to corrective action requests can help to streamline the quality assurance process and build confidence in the food safety practices of the studied abattoirs. However, external auditing still find its place in its objective nature, fresh perspectives and conformance to standards.

In support of practices from elsewhere (Howlett et al. 2005), auditors were using a guidance checklist in their auditing to ensure effective implementation and compliance with standard requirements and the majority of respondents were aware of areas to be audited. However, the major observed fault on the checklist used in this study was its lack of objective assessment criteria and this could probably explain the respondents' cited faults on the current audit system such as fault finding, not objective, not transparent, not standardised and not measured against published standards. Armstrong (1999) pointed out that an audit without any objective standards will inevitably fail because employees do not understand the basis on which their activities are judged. The audit checklist should include; location of the inspection, assessment criteria to evaluate whether each criterion was satisfactorily adhered to or not, compliance or non-compliance and objective evidence for each incomplete criterion identified (Howlett et al. 2005). Furthermore, the assessment criteria should be based on critical, major and minor non-compliance where critical non-compliance refers to a failure to comply with food safety legislation such as the presence of specified risk material on a carcass (Howlett et al. 2005). Major non-compliance is where there is substantial failure to meet the requirements of a statement of intention such as no training records for a production line operative whilst a minor non-compliance is not an immediate food risk to the consumer (Howlett et al. 2005). It has been reported that ill-conceived audits may cause problems and confusion especially in the area of food safety (Armstrong 1999). Recently, food safety objectives (FSO) and performance objectives (PO) have been set for the food industry (International Commission on Microbiological Specifications for Foods [ICMSF] 2002). The FSO is the maximum frequency and/or concentration of a microbiological hazard in a food at the time of consumption that provides the appropriate level of protection whilst the $\mathrm{PO}$ are the concentration limits earlier in the food processing and distribution chain that allow the product to meet the FSO (International Commission on Microbiological Specifications for Foods [ICMSF] 2002). It is therefore imperative for the competent authorities and slaughterhouse operators in the country to jointly formulate FSOs and POs so as to objectively express the level of hazard control that is required to meet public health goals.
General food law for all stages of food production within the EU is covered by regulation (EC) $178 / 2002$, which lays down a basic legal framework of food safety measures that must be carried out to protect consumer health and to allow free trade of safe food that meets consistent standards (Adams \& Brülisauer 2010). Results of the present study showed that slaughterhouse operations are governed by law and the majority of abattoir respondents were aware of the legislation and consequences of breaching regulations. The major fault of the current legislation is that there are no requirements for a QA programme for slaughterhouses. This could probably explain the minimal to no implementation of QA programmes in the studied abattoirs. Regulations have been reported to force food operators to implement QA systems such as a FSMS in order to control the outbreaks of food-borne illnesses (Schlundt 2002; Luning, Devlieghere \& Verhé 2006; Tsalo, Drosinos \& Zoiopoulos 2007; Jacxsens et al. 2009a). Thus, slaughterhouse operators of the studied abattoirs should establish and implement QA systems in order to improve food safety. Competent authorities in the country should take into account the contribution of such QA systems to food safety during routine verification of regulatory requirements.

It is now generally acknowledged that traditional meat inspection procedures cannot assure that consumers will not be exposed to infectious doses of meat-borne pathogens (Tompkin 1990). Consequently, meat inspecting authorities around the world are currently encouraging or mandating the implementation of HACCP systems for meat production processes (Brown et al. 2000). The recently developed FSMS based on GHP and HACCP principles addresses both food safety control and assurance activities in order to guarantee food safety (Luning \& Marcelis 2007). A microbial assessment scheme (MAS), a tool for a systematic assessment of the current microbial performance of an implemented FSMS has been developed (Jacxsens et al. 2009b). Based, on the MAS, low numbers of microorganisms and small variations in their counts indicate an effective FSMS (Jacxsens et al. 2009b). In addition, a food safety management system diagnostic instrument (FSMS-DI) (Luning et al. 2008; Luning et al. 2009) and food safety performance indicators (FSPI) (Jacxsens et al. 2010) have been developed to assess the performance of a FSMS independent of QA standards implemented and without performing the actual microbiological analysis. Results of the present study showed that implementation of QA systems is non-existent to minimal and slaughterhouse operators in Zimbabwe are recommended to implement the above QAs to meet international trends in food safety. Additionally, the competent authorities should facilitate adoption of these new processing technologies and other developments in meat hygiene where scientific evaluation has shown that they achieve required outcomes in terms of food safety.

Abattoirs should view audit and quality inspection results as opportunities for corrective action where identified nonconformances should be eliminated. Using the audit process 
as an opportunity for continual improvement could assist slaughterhouse operators to better meet the dynamic needs of food safety (Hepner et al. 2004). Analysis of audit and quality communications to the studied abattoirs revealed a wide variety of shortfalls with a general non-response to audit and quality recommendations and this was supported by the majority of respondents. It is a challenge to compel food producers to adhere to recommended standards, especially in the absence of an outbreak. The non-replacement or repair of non-functional equipment could probably be attributed to budgetary constraints and lack of foreign currency due to the economic depression experienced in the country in the past 10 years. However, pressure for high production at all costs with no regard to quality and legal requirements was noted. The largest human outbreak of Escherichia coli O157:H7 in Wales in 2005 (Griffith 2010) was attributed to little regard for the importance of food safety but where making and saving money was the priority (Griffith 2010). Evidence provided by employees indicated inadequate cleaning of equipment and facilities, poor maintenance and damaged construction, as well as inadequately trained staff with poor hygiene habits (Griffith 2010). During the present study, inadequate training on quality and legislation was highlighted by respondents.

Based on the report by Jacxsens et al. (2010), external and internal FSPI such as comprehensiveness of external audits, seriousness of external audit remarks, type of microbiological food safety and hygiene-related complaints by customers, extent of product sampling, comprehensiveness of microbiological criteria and type of hygiene and pathogen non-conformities, the FSMS of the abattoirs in the current study may be ranked as poor to moderate. However, given the high level of awareness amongst the respondents on the benefits of audits and areas to be audited, and external evaluation by the competent authority, it is imperative for these abattoirs to develop a strong and positive food safety culture. The food safety culture must take precedence over other competing cultures including that of money saving (Griffith, Livesey \& Clayton 2010). Therefore, the abattoirs should develop a FSMS comprising of QA programmes, MAS, regulatory compliance, standard operating procedures, policies, training, internal and external auditing, awareness of responsibilities, management commitment and communication efforts.

\section{Acknowledgements Competing interests}

The authors declare that they have no financial or personal relationships, which may have inappropriately influenced them in writing this article.

\section{Authors' contributions}

K.E.M. (Veterinary Public Health Department, Bulawayo, Zimbabwe) administered the questionnaire and wrote the manuscript; G.M. (University of Zimbabwe) and D.M.P (University of Zimbabwe) were the project leaders, did the data analysis and also assisted in the writing of the manuscript.

\section{References}

Adams, K. \& Brülisauer, F., 2010, 'The application of food safety interventions in primary production of beef and lamb: A review', International Journal of Food Microbiology 141, S43-S52. http://dx.doi.org/10.1016/j.ijfoodmicro.2009.12.020, PMid:20097438

Albersmeier, F., Schulze, H., Jahn, G. \& Spiller, A., 2009, 'The reliability of third-party certification in the food chain: From checklists to risk-oriented auditing', Food Control 20, 927-935. http://dx.doi.org/10.1016/j.foodcont.2009.01.010

Armstrong, G.D., 1999, 'Towards integrated hygiene and food safety management systems: The hygieneomic approach', International Journal of Food Microbiology 50, 19-24. http://dx.doi.org/10.1016/S0168-1605(99)00073-2

Benet, J.J. \& Bellemain, V., 2005, 'Responding to consumer demands for safe foods: A major role for veterinarians in the 21st century', Paper presented at the 28th World Veterinary Congress, OIE Seminar: Challenges in responding to new international and social demands on the veterinary profession, Minneapolis, USA 16-20 July 2005.

Benet, J.J., Dufour, B. \& Bellemain, V., 2006, 'The organization and functioning of veterinary services: Results of a 2005 survey of member countries of the World Organization for Animal Health,' Reveu Scientifique et Technique International Office of Epizootics 25, 739-761.

British Retail Consortium (BRC), 2008, Global standard for food safety, TSO, Norwich.

Brown, M.H., Gill, C.O., Hollingsworth, J., Nickelson II, R., Seward, S., Sheridan, J.J., et al., 2000, 'The role of microbiological testing in systems for assuring the safety of beef', International Journal of Food Microbiology 62, 7-16. http://dx.doi. org/10.1016/S0168-1605(00)00408-6

CIES, 2007, 'Global food safety initiative guidance document', 5th edn., viewed 08 August 2010, from foodsafety@ciesnet.com

Cormier, R.J., Mallet, M., Chiasson, S., Magnússon, H. \& Valdimarsson, G., 2007 'Effectiveness and performance of HACCP-based programs', Food Control 18, 665-671. http://dx.doi.org/10.1016/j.foodcont.2006.02.019

Domenech, E., Escriche, I. \& Martorell, S., 2008, 'Assessing the effectiveness of critical control points to guarantee food safety', Food Control 19, 557-565. http://dx.doi. org/10.1016/j.foodcont.2007.06.015

Griffith, C.J., 2010, 'Do businesses get the food poisoning they deserve? The importance of food safety culture', British Food Journal 112, 416-425. http:// dx.doi.org/10.1108/00070701011034420

Griffith, C. J., Livesey, K. M. \& Clayton, D., 2010, 'Food safety culture: The evolution of an emerging risk factor', British Food Journal 112, 426-438. http://dx.doi. org/10.1108/00070701011034439

Government of Zimbabwe, 1945, Slaughtering and meat inspection regulation, Government Printers, Salisbury.

Government of Zimbabwe, 1984, Statutory instruments 111: Produce export (abattoir, slaughter and meat hygiene) regulation, Government Printers, Harare.

Government of Zimbabwe, 1995, Statutory instruments 50: Public health (abattoir animal and bird slaughter and meat hygiene) regulation, Government Printers, Harare.

Government of Zimbabwe, 1996, Public Health Act, rev. edn, ch. 15, p. 9, Government Printers, Harare.

Hepner, I., Wilcock, A. \& Aung, M., 2004, 'Auditing and continual improvement in the meat industry in Canada', British Food Journal 106, 553-568. http://dx.doi. org/10.1108/00070700410545746

Howlett, B., Bolton, D.J. \& O Sullivan, G., 2005, 'Auditing of pre-requisite programmes and HACCP principles in Irish beef slaughterhouses', Teagasc, the National Food Centre, National Development Plan 2000-2006, Ashtown, Dublin.

International Commission on Microbiological Specifications for Foods (ICMSF), 2002 'Microorganisms in foods: Microbiological testing in food safety management', vol. 7, Kluwer Academic/Plenum, New York.

International Food Standard (IFS), 2007, 'Standard for auditing, retailer and wholesaler branded food products', HDE Trade Services, Berlin.

ISO, 2005, 'Food safety management systems - Requirements for any organization in the food chain', ISO 22000:2005, ISO, London.

Jacxsens, L., Devlieghere, F. \& Uyttendaele, M., 2009a, 'Quality management systems in the food industry', St Kliment Ohridski University Press, Sofia.

Jacxsens, L., Kussaga, J., Luning, P.A., Van der Spiegel, M., Devlieghere, F. \& Uyttendaele, M., 2009b, 'A Microbial assessment scheme to measure microbial performance of food safety management systems', International Journal of Food Microbiology 134 113-125. http://dx.doi.org/10.1016/j.ijfoodmicro.2009.02.018, PMid:19327860

Jacxsens, L., Uyttendaele, M., Devlieghere, F., Rovira, J., Oses Gomez, S. \& Luning, P.A., 2010, 'Food safety performance indicators to benchmark food safety output of food safety management systems', International Journal of Food Microbiology 141 S180-S187. http://dx.doi.org/10.1016/j.ijfoodmicro.2010.05.003, PMid:20580985

Jacxsens, L., Luning, P.A., Marcelis, W., J., Van Boekel, T., Rovira, J., Oses, S., Kousta, M., Drosinos, E., Jasson, V. \& Uyttendaele, M., 2011, 'Tools for the performance assessment and improvement of food safety management systems', Food Science and Technology 22, S80-S89. http://dx.doi.org/10.1016/j.tifs.2011.02.008

Luning, P.A. \& Marcelis, W.J., 2007, 'A food quality management functions model from a techno-managerial perspective', Trends in Food Science and Technology 18, 159-166. http://dx.doi.org/10.1016/j.tifs.2006.10.021

Luning, P.A., Devlieghere, F. \& Verhé, R., 2006, Safety in agrifood chains, Wageningen Academic Publishers, Wageningen. 
Luning, P.A., Bango, L., Kussaga, J., Rovira, J. \& Marcelis, W.J., 2008, 'Comprehensive analysis and differentiated assessment of food safety control systems: A diagnostic instrument', Trends in Food Science and Technology 19, 522-534. http://dx.doi. instrument', Trends in Food Scienc
org $/ 10.1016 /$ j.tifs.2008.03.005

Luning, P.A., Marcelis, W.J., Rovira, J., Van der Spiegel, M., Uyttendaele, M. \& Jacxsens, L., 2009, 'Systematic assessment of core assurance activities in company specific
food safety management systems', Trends in Food Science and Technology 20, 300-312. http://dx.doi.org/10.1016/j.tifs.2009.03.003

Luning, P.A., Marcelis, W. J., Rovira, J., Van Boekel, M.A.J.S., Uyttendaele, M. \& Jacxsens, L., 2011, 'A tool to diagnose context riskiness in view of food safety activities and microbiological safety output', Food Science and Technology 22 S67-S79. http://dx.doi.org/10.1016/j.tifs.2010.09.009

Mckenzie, A.I. \& Hathaway, S.C., 2006, 'The role and functionality of veterinary services in food safety throughout the food chain', Reveu Scientifique et Technique International Office of Epizootics 25, 837-848. PMid:17094715

Sampers, I., Toyofuku, H., Luning, P.A., Uyttendaele, M. \& Jacxsens, L., 2012, 'Semiquantitative study to evaluate the performance of a HACCP-based food safety management system in Japanese milk processing plants', Food Control 23, 227233. http://dx.doi.org/10.1016/j.foodcont.2011.07.018
Schlundt, J., 2002, 'New directions in foodborne disease prevention,' International Journal of Food Microbiology 78, 17-25. http://dx.doi.org/10.1016/S01681605(02)00234-9

Tompkin, R.B., 1990, 'The use of HACCP in the production of meat and poultry products', Journal of Food Protection 53, 795-803.

Tsalo, E., Drosinos, E.H. \& Zoiopoulos, P., 2007, 'Impact of poultry slaughter house modernization and updating of food safety management systems on the microbiological quality and safety of products', Food Control 19, 423-431.

Van der Spiegel, M., Luning, P.A., Ziggers, G.W. \& Jongen, W.M.F., 2005, 'Development of the instrument IMAQE-food to measure effectiveness of quality management' International Journal of Quality and Reliability Management 22, 234-255. http:// dx.doi.org/10.1108/02656710510582471

Van Gerven, T., Block, C., Geens, J., Cornelis, G. \& Vandecasteele, C., 2007, 'Environmental response indicators for the industrial and energy sector in
Flanders', Journal of Cleaner Production 15, 886-894. http://dx.doi.org/10.1016/j. jclepro.2006.01.016

Wallace, C.A., Powell, S.C. \& Holyoak, L., 2005, 'Development of methods for standardized HACCP assessment', British Food Journal 107, 723-742. http:// dx.doi.org/10.1108/00070700510623513 